\title{
Encouraging Assessment of the Educational Climate in Medical Schools under the MEPI-MESAU Consortium
}

\section{Conrad Ondieki Miruka*}

Kampala International University-Western Campus, P.O. BOX 71, Bushenyi, Uganda

${ }^{*}$ Corresponding author: Conrad Ondieki Miruka, Kampala International University-Western Campus, P.O. BOX 71, Bushenyi, Uganda, Tel: +256777410403; E-mail: conradmiruka@yahoo.com

Rec date: Nov 13, 2015; Acc date: Nov 16, 2015; Pub date: Nov 18, 2015

Copyright: ( 2015 Miruka CO, et al. This is an open-access article distributed under the terms of the Creative Commons Attribution License, which permits unrestricted use, distribution, and reproduction in any medium, provided the original author and source are credited.

\section{Editorial}

The educational environment is one of the most important factors that determine the effectiveness of an undergraduate medical curriculum. There are many evaluations (both qualitative and quantitative) that have been conducted globally to measure the academic environment of health sciences programmes (undergraduate and postgraduate) by utilising different methodologies. These evaluations include assessment of medicine, nursing, physiotherapy, dental science, chiropractic and other related programmes [1]. The World Federation for Medical Education notes the learning environment to be one of the targets for the evaluation of medical education programs [2]. Student's perception of the educational environment has been designated as the educational climate (EC) and consequently, it has been defined as "the soul and the spirit of the medical school environment and curriculum" $[3,4]$. Because of its role in influencing teacher behavior, behavioral development of students, and its implication in the achievement of corporate goals and the level of satisfaction obtained, the educational climate must be taken into serious consideration [5-9]. It can serve as a stimulus for change since it has been considered as an expression, manifestation and measure of a curriculum [10]. The Dundee Ready Educational Environment Measure (DREEM), developed by Roff et al. in 1997 has been widely used as principal tool in measuring the educational climate. The DREEM is a general, multidimensional, multicultural instrument. It gives a universal score of a maximum of 200 and is capable of measuring five separate elements of the education environment: Students' Perceptions of Learning (SPoL), Students Perceptions of Teachers (SPoT), Students Perceptions of Atmosphere (SPoA), Students' Academic Self-Perception (SASP), and Student's Social SelfPerceptions (SSSP) [11]. The instrument can be used to highlight the weaknesses and strengths of any educational institution, compare the performance and success of medical schools, and make comparisons among students in different levels of study and of different sex $[9,12]$.

Measurement of the educational climate can provide medical educators with a comprehensive view of the curriculum that is delivered $[5,13]$. There are studies that have pointed out that since a change in the educational environment can affect students achievements, satisfaction and success, an assessment of the curriculum's environment is a must to ensure the delivery of highquality teaching $[14,15]$. In recent times, it has been established that the use of DREEM plays a role in providing a consistent method for global comparisons between medical schools and also, in allowing them to standardize their educational environments [16].

The increased recognition of a need to evaluate the educational environment of medical schools has been prompted by various factors. These include innovations in medical curricula (which include a blend of classroom, workplace, clinical and community-based learning) and increasing diversity of the student population in medical courses. In turn, evaluation helps to assess if these curricula are beneficial to students and adding to their skills as compared to the traditional counterparts, and to draw lessons for continuous improvement [17].

The Medical Education for Equitable Services to All Ugandans (MESAU) Consortium is a country-wide partnership comprising of Busitema University, Gulu University, Kampala International University, Makerere University and Mbarara University of Science and Technology in Uganda. The consortium receives support from Johns Hopkins University in order to catalyze capacity and performance enhancements in medical education and relevant research with a focus on excellent, nationwide service delivery. With the overarching vision of "Medical education for equitable service delivery to All Ugandans", the consortium has the main goal of developing MESAU institutions as centres of excellence for medical education, research and service that address local and national needs to improve health in Uganda.

The aims of the consortium are; improving the quality and relevance of medical education and service training in Uganda, providing incentives and support to faculty and students to undertake locally driven trans-disciplinary research on topics relevant to Uganda and facilitating efficient conduct of education to increase number of HWs trained and research through support systems capacity building. The Medical Education Partnership Initiative (MEPI) supports medical education and research in Sub-Saharan African institutions. The purpose of the MEPI support is to ensure an increase in the quantity, quality and retention of graduates with specific skills addressing the health needs of their national populations. MEPI is based on the idea of transformative medical education which is premised on the understanding that the attributes of a nation's health care workers (HCWs), including their education, the health system, and the health of the population are interrelated. There are three themes emphasized in MEPI sponsored investments in education, namely; increasing the numbers of HCWs trained, retaining HCWs over time and in areas where they are most needed and supporting regionally relevant research.

The initiative envisions strong links among MEPI institutions and between the institutions and their respective ministries of health and education. Such linkages are deemed essential to promote planning in a collaborative manner, graduate retention, and the sustainability of innovations in education and research. MEPI requires that all interventions have clear, measurable outcomes. The success of MEPI programs will be judged on outcomes achieved with an emphasis on their impact on population health [18]. Published information on assessment of educational climate in Ugandan medical schools is hard 
to come by. Since this assessment of educational climate has been pointed out to be a stimulus for change, it can easily enable institutions under the MEPI-MESAU consortium to achieve some the varied objectives which the consortium envisions to achieve. It can also help the institutions to identify the problematic areas which need to improve so as to facilitate better delivery of the medical curricula. Studies to assess the educational climate in these institutions can be conducted with each institution doing its independent study or all the five member institutions conducting an umbrella study under a common guidance team. Such an umbrella study was recently published from Spain with very interesting findings [19]. The Spanish study, which was conducted under the Spanish Society for Medical Education (SEDEM), entailed a cross-sectional study in different medical schools to analyze the perception of EC by 2 nd and 4 th year students. It had several objectives, including; to determine whether the perception of the EC by medical students, is different between the 2nd and the 4th year, (i.e., basic versus clinical period), to determine how the curricular change is developing, particularly after the transition between the preclinical and clinical periods and to identify the strengths and weaknesses in the new curriculum as they relate to the educational environment after 4 years of Bologna implementation.

Therefore it is highly recommended that similar studies be carried out in Ugandan medical schools so as to enable medical educators in the country to better design ways of improving the EC and also to determine better ways of delivering the medical curricula. Such studies should ideally be undertaken on a yearly basis in the medical schools as part of the quality assurance's mechanisms of identifying areas in the EC that require improvement or persistent problematic areas which can then be addressed over time by the institutions sponsors or management trustees. Such studies can also form a basis for decisions in future directions in interventions to improve the medical schools in the country.

\section{References}

1. Soemantri D, Herrera C, Riquelme A (2010) Measuring the educational environment in health professions studies: a systematic review. Med Teach 32: 947-952.

2. Tackett S, Grant J, Mmari K (2015) Designing an evaluation framework for WFME basic standards for medical education. Med Teach .

3. Genn JM (2001) AMEE Medical Education Guide No. 23 (Part 1): Curriculum, environment, climate, quality and change in medical education-a unifying perspective. Med Teach 23: 337-344.
4. Hutchinson L (2003) The $\mathrm{ABC}$ of learning and teaching: educational environment. BMJ326: 810-812.

5. Roff S, McAleer S (2001) What is educational climate? Med Teach 23 333-334.

6. Plucker JA (1998) The relationship between school climate conditions and student aspirations. J Educ Res 91: 240-246.

7. Pimparyon P, Roff S, McAleer S, Poonchai B, Pemba S (2000) Educational environment, Student approaches to learning and academic achievement in a Thai nursing school. Med Teach 22: 359-364.

8. Lizzio A, Wilson K, Simons R (2002) University student's perceptions of the learning environment and academic outcomes: implications for theory and practice. Stud Higher Educ 1: 27-52.

9. Mayya S, Roff S (2004) Students' perceptions of educational environment: a comparison of academic achievers and under-achievers at kasturba medical college, India. Educ Health (Abingdon) 17: 280-291.

10. Harden RM (2001) The learning environment and the curriculum. Med Teach 23: 335-336.

11. Roff S, McAleer S, Harden RM, Al-Qahtani M, Uddin AA, et al. (1997) Development and validation of the Dundee ready education environment measure (DREEM). Med Teach 19: 295-309.

12. Roff S, McAleer S, Ifere OS, Bhattacharya S (2001) A global diagnostic tool for measuring educational environment: comparing Nigeria and Nepal. Med Teach 23: 378-382.

13. Genn JM, Harden RM (1986) What is medical education here really like? Suggestions for action research studies of climates of medical education environments. Med Teach 8: 111-124.

14. Cavanaugh S, Simmons P (1997) Evaluation of a school climate instrument for assessing affective objectives in health professional education. Eval Health Prof 20: 455-478.

15. Pemba S, Primparyon P, Roff S, McAleer S (2000) Educational environment, student approaches to learning and academic achievement in a Thai nursing school. Med Teach 22: 359-364.

16. Hammond SM, O'Rourke M, Kelly M, Bennett D, O'Flynn S (2012) A psychometric appraisal of the DREEM. BMC Med Educ 12: 2.

17. Miles S (2011) Changes in medical education: Examining the student's views. In: Cavenagh P, Leinster SJ, Miles S (Eds) the changing faces of medical education, Abingdon, UK: Miles Radcliffe Publishing Ltd, pp: $103-$ 115.

18. MAKCHS (2015) Medical Education for Equitable Services to All Ugandans (MESAU).

19. Palés J, Gual A, Escanero J, Tomás I, Rodríguez-de Castro F, et al. (2015) Educational climate perception by preclinical and clinical medical students in five Spanish medical schools. Int J Med Educ 6: 65-75. 